\title{
РОЗВИТОК КРИТИЧНОГО МИСЛЕННЯ СТАРШОКЛАСНИКІВ У ПРОЦЕСІ ЗАСТОСУВАННЯ ЦИФРОВИХ ТЕХНОЛОГІЙ
}

\author{
Артем Коркішко \\ кандидат педагогічних наук, \\ старший викладач кафедри педагогіки вищої школи \\ ДВНЗ «Донбаський державний педагогічний університет» \\ м. Слов'янськ, Україна \\ ORCID ID 0000-0002-4821-1312 \\ slavpedlicey@ukr.net \\ Марина Калмикова \\ учитель-методист, учитель української мови й літератури \\ Слов’янський педагогічний ліцей Слов’янської міської ради Донецької області
м. Слов'янськ, Україна
slavpedlicey@ukr.net

\begin{abstract}
Анотація. У статті проаналізовано можливості використання цифрових технологій для розвитку критичного мислення старшокласників у процесі проєктної діяльності й на уроках вивчення філологічних дисциплін. Визначено взаємозв'язок між залученням старшокласників до використання цифрових технологій у процесі навчання й розвитком здатності учнів працювати з інформаційним потоком, формулювати власну точку зору на основі усвідомлення різноманітного досвіду, ідей та уявлень; розв’язувати проблеми; займатися власною освітою й визначати індивідуальну освітню траєкторію; розвивати вміння співробітничати й працювати в групі, здатність будувати конструктивні стосунки 3 іншими людьми. Актуалізовано необхідність пошуку більш ефективних шляхів впровадження цифровізації як комплексу інструментів, що оптимізують навчання, забезпечують персоналізацію освітніх процесів.
\end{abstract}

Ключові слова: цифровізація освіти; цифрові технології; критичне мислення; медіаосвіта; інформаційно-цифрова компетентність.

Постановка проблеми в загальному вигляді. Епоха цифрового суспільства потребує сьогодні вільного володіння навичками для успішного використання можливостей нової, цифрової реальності. Зазнали помітних змін технології для передавання інформації; значно розширився спектр засобів масмедіа: вони стали мобільними, інтернет-соціальними; відбулася докорінна зміна їх призначення й застосування. Реформування освіти України також неможливе сьогодні без активного застосування в навчанні цифрових технологій і вироблення цифрових компетентностей учасників освітнього процесу. Про це, зокрема, йдеться в Проєкті концепції цифрової трансформації освіти і науки (2021): «Сьогоднішня система освіти і науки має зазнати докорінних цифрових змін та відповідати світовим тенденціям цифрового розвитку для успішної

Професіоналізм педагога: теоретичні й методичні аспекти. Методичні матеріали до проєкту «Цифровий освітній простір: українсько-польський досвід». - Слов’янськ, 2021. 
Розвиток критичного мислення старшокласників у процесі застосування цифрових технологій

реалізації кожною людиною свого потенціалу» (Проєкт концепції цифрової трансформації освіти і науки, 2021).

Проблема знайшла свого відображення в Законі України «Про освіту» (2017), Концепції «Нова українська школа» (2016), де з-поміж ключових освітніх компетентностей зроблено акцент на формуванні інформаційно-цифрової компетентності, що передбачає «впевнене, а водночас критичне застосування інформаційно-комунікаційних технологій для створення, пошуку, обробки, обміну інформацією» (Концепція «Нова українська школа», 2016).

Особливого значення набуває застосування цифрових технологій у процесі набуття медіаосвіти й формування критичного мислення учнів - важливого чиннику розвитку особистості, що виробляє вміння здобувати й опрацьовувати інформацію, самостійно аналізувати, систематизувати матеріал, удосконалювати ключові освітні компетентності й обумовлює актуальність проблеми пошуку ефективних форм і методів такого навчання.

Аналіз останніх досліджень і публікацій. Покликаючись на дослідження І.Кучерак (2020), зауважимо, що різні аспекти впровадження цифровізації в освітній простір стали предметом дослідження зарубіжних (К. Бассет (C. Bassett)， К. Гере (С. Gere), Г. Грибер (G. Creeber), М. Деузе (M. Deuze), Г. Крибер і Р. Мартін (G. Greeber \& R. Martin), Л. Манович (L. Manovich), Дж. Стоммел (J. Stommel), M. Хенд (M. Hand) і вітчизняних (В. Биков, Д. Галкін, М. Жалдак, М. Лещенко, П. Матюшко, О. Овчарук, В. Ребрина, О. Стрижак, М. Шишкіна, А. Яцишин) науковців, які передбачають упровадження нової цифрової освітньої парадигми, побудови навчального процесу на кросплатформовому форматі з використанням новітніх методик; підвищення таким чином конкурентоспроможності, ефективної взаємодії всіх учасників освітнього процесу, ролі інтелектуальної власності, розвитку цифрових навичок здобувачів освіти тощо.

Запровадження цифрових технологій є невід'ємним чинником розвитку критичного мислення учнів, підгрунтям продуктивних методів і технологій навчання, що дістали грунтовного розгляду в працях таких дослідників, як А. Байрамов, О. Береза, I. Васюта, С. Векслер, Т. Воропай, О. Коржуєв, М. Лімпман, А. Липкіна, Л. Рибак, І. Родигіна, О. Тягло, Г. Строганова, М. Шеремет. Дослідники визначають критичне мислення як чинник розвитку особистості, самостійне, інформативне, раціональне, рефлексивне, самодостатнє, аргументоване, багатомірне, соціальне мислення школяра, у ході продуктивної діяльності якого формується позитивний досвід, оскільки тут учень має змогу демонструвати вміння здобувати й опрацьовувати інформацію, самостійно аналізувати, систематизувати матеріал. 
Розвиток критичного мислення старшокласників у процесі застосування цифрових технологій

Повноцінний розвиток у здобувачів освіти інформаційно-цифрової компетентності, здатності мислити критично можливий за умови формування позитивної мотивації навчання й цілеспрямованого педагогічного впливу на розвиток кожного з компонентів розумової і творчої діяльності учня.

Формулювання цілей статті (постановка завдання). Мета статті дослідити ефективність застосування цифрових технологій у процесі розвитку критичного мислення старшокласників під час проєктної діяльності на прикладі досвіду Слов'янського педагогічного ліцею.

Результати дослідження. На сучасному етапі розвитку освіти цифровізація $є$ відображенням нової парадигми розвитку суспільства, життєво необхідною якістю, що, на думку С. Карплюк, сприяє вдосконаленню освітнього процесу, роблячи його більш гнучким, пристосованим до реалій сучасного дня, $\mathrm{i}$ забезпечує формування конкурентоспроможних професіоналів (Карплюк, 2019, c. 188).

Як зазначає дослідниця І. Кучерак (2020), цифрові технології сприяють:

- розвитку вмінь учнів навчатися самостійно, виокремлювати найбільш цінний матеріал для саморозвитку;

- формуванню мобільності особистості, умінь швидко адаптуватися до умов, що змінюються;

- посиленню мотивації до самоосвіти та саморозвитку;

- персоналізації освітнього контенту, забезпеченню інтегративності процесу навчання;

- побудові індивідуальної освітньої траєкторії здобувачів освіти;

- навчанню у найбільш зручних умовах, комфортному темпі, 3 оптимальним використанням часу тощо.

Та, найголовніше, на думку I. Кучерак (2020), діджиталізація забезпечує перехід від «освіти для всіх до освіти для кожного», відрізняється дидактичним потенціалом, що забезпечує свободу пошуку інформації, ii персоналізацію (орієнтацію на потреби учнів - різний рівень складності, темп, подача матеріалу), інтерактивність, мультимедійність, субкультурність.

Цифрові технології є міцним підгрунтям медіаосвіти молоді, що $є$, зокрема, частиною базових прав кожного громадянина в кожній країні світу на свободу висловлювання та на доступ до інформації; інструментом розбудови та дотримання демократії (Волошенюк \& Іванов, 2013, с. 8-9).

Платформи для створення медіаконтенту та поєднання продуктів різних форм інтуїтивно зрозумілі й прості у використанні. Ця нова мова людської комунікації стає все доступнішою й простішою та започатковує нові види в 
Розвиток критичного мислення старшокласників у процесі застосування цифрових технологій

кожній галузі, наприклад, у цифровому мистецтві: інтерактивні інсталяції, мультимедіа-перформанси, мережеві арт-проекти, експерименти з віртуальними реальностями тощо.

Позитивним у цьому контексті можна вважати досвід учителів і учнів Слов'янського педагогічного ліцею зі створення навчальних анімаційних роликів, що поєднують у собі цікаве викладення матеріалу та демонстрацію його застосування. Ідея залучення старшокласників до такої діяльності належить учителю інформатики ліцею Ю. Іваненку.

Розуміючи складність такого процесу, педагог, тим не менш, запропонував учням спробувати опанувати програми Adobe Flash, Easy Gif Animator та Anime Studio. Такий вибір був зумовлений тим, що звичайно навчальні анімаційні ролики створюють програмісти, або викладачі, тому школярам досить часто не цікавою є форма подання навчального матеріалу. Тож ідея полягала в тому, щоб такі ролики створювали не дорослі, а самі школярі, які краще розуміють, як подати матеріал одноліткам для кращого сприйняття.

Було створено творчу учнівську групу, яку очолила учениця 9 класу Кулєшова Наталія, захоплена ідеєю навчальних розробок на зразок мультфільмів Роберта Саакаянца, у яких головні герої у формі гри вчили рахувати, писати, давали відомості з географії, історії тощо. Реалізація спільної ідеї дала змогу учениці здійснити істотний крок у самоосвіті й саморозвитку, сформувала підвалини критичного мислення: уміння обирати головне, опрацьовувати інформацію, самостійно аналізувати, систематизувати матеріал. Навчаючись основам програмування, отримуючи від учителя консультації й поради, Наталія, однак, розвивала цікавий ій аспект такої діяльності: створювала коротенькі ролики для уроків геометрії, вдосконалювала їх, апробовувала в мережі Інтернет.

Один 3 роликів, надісланий старшокласницею на конкурс «Indie Media Сатр», здобув перемогу; 3'явилася можливість відвідати Фінляндію за програмою «Обдаровані діти», що спонукало ліцеїстку до подальшої роботи в обраному напрямі: було створено дві частини анімаційного відеоролика про Ілона Маска, які сьогодні використовують на своїх уроках учителі фізики та економіки; фільми про виникнення соціальної мережі Facebook та історії корпорації Apple.

Ці роботи брали участь у Всеукраїнському конкурсі «ITalent» (перший та найбільший в Україні конкурс з IT-проєктів та кіберспорту серед молоді віком до 19 років), де отримали високі оцінки від журі; згодом учениця здобула перемогу на III етапі Всеукраїнського конкурсу-захисту Малої академії наук України в секції «мультимедійні системи, навчальні та ігрові програми». У 2020 р. ліцеїстка здобула грант проєкту EASYSIGN, реалізованого UNICEF 
Розвиток критичного мислення старшокласників у процесі застосування цифрових технологій

Ukraine за фінансової підтримки Уряду Японії й спрямованого на підвищення поінформованості людей про проблеми нечуючих та популяризацію жестової мови (створення веб-додатку). Кулєшова Наталія як автор EASYSIGN стала фіналістом UPSHIFT Україна. Така перемога скоригувала розвиток старшокласниці в обраному напрямі, сприяла зростанню громадської активності, зробила діяльність учениці соціально значущою.

У 2021 р. юною дослідницею було розроблено веб-додаток для імітації тваринного зору, що дало їй змогу стати фіналісткою програми Ukraine Global Scholars. Тож захоплення цифровими технологіями сприяло розвиткові критичного мислення ліцеїстки, його самостійності, рефлективності, багатовимірності, соціальності; зумовило подальший вибір фаху та індивідуальної освітньої траєкторії.

Нового вектору розвитку у контексті запровадження цифрових технологій набуває й діяльність вчителя й учнів на уроках філологічних дисциплін, зокрема української літератури, коли освітньо-пізнавальна діяльність відбувається комплексно: у руслі художнього твору, інформації про нього й тих цифрових технологій, що будуть найдоцільнішими у відтворенні творчого задуму. Реалізація таких завдань $є$ можливою лише на уроках співтворчості, побудованих на абсолютно паритетних умовах, де вчитель і учень, як рівний із рівним, намагаються осягнути у спільній праці вершини прекрасного, де головне місце в роботі надається учневі, а на вчителя покладаються організаторські функції: як скерувати роботу, у яке русло спрямувати думки, що́ необхідне для розуміння й презентації твору тощо.

Критичне мислення учнів тут розвивається в процесі систематичної роботи зі створення творчого продукту - буктрейлерів, мистецьких виставок, віртуальних бібліотек, мультимедійних сценаріїв, презентацій, плейкастів, скрапбуків, блогів тощо, участі в різноманітних проєктах, - що потребує від учнів певного рівня інформаційно-цифрової компетентності. Значно поглибила цифрові уміння й навички старшокласників Слов'янського педагогічного ліцею участь у проєкті «Люди свободи», присвяченому проблемі українського дисидентського руху. Об'єктом дослідження учнів 10-11 класів упродовж року стала творчість Василя Стуса, Олекси Тихого, Миколи Руденка, результатом якої стало створення буктрейлерів, мистецьких проєктів, один 3 яких - інтерв'ю 3 дослідником життя і творчості Олекси Тихого Володимиром Півнем - здобуло перемогу обласного конкурсу.

Провідна роль педагога-словесника полягала в тому, щоб допомогти дитині осягнути насамперед саму себе, відчути радість від свого розуму, емоцій, 
Розвиток критичного мислення старшокласників у процесі застосування цифрових технологій

своєї неповторності, розвинути інформаційно-цифрову компетентність, а відтак виховати позитивні почуття від результату власної творчості.

Висновки з дослідження і перспективи подальших розвідок у цьому напрямі. Систематична робота із застосування цифрових технологій в освітній діяльності формує в учнів здатність працювати з інформаційним потоком, формулювати власну точку зору на основі усвідомлення різноманітного досвіду, ідей та уявлень; розв'язувати проблеми; займатися власною освітою й визначати індивідуальну освітню траєкторію; уміння співробітничати й працювати в групі; здатність будувати конструктивні стосунки з іншими людьми. Проте цифрові технології мають бути лише зручним засобом для досягнення цілей розвитку кожної особистості, які не лише вчитель, а й кожна дитина має вчитись ставити перед собою. Перспективу подальших розвідок у цьому контексті становить проблема пошуку більш ефективних шляхів впровадження цифровізації як комплексу інструментів, що оптимізують навчання, забезпечують персоналізацію освітніх процесів.

\section{СПИСОК ВИКОРИСТАНИХ ДЖЕРЕЛ}

1. Волошенюк, О. В. і Іванов, В. Ф. (Ред.). (2013). Медіаосвіта та медіаграмотність: підручник. Київ, Україна: Центр Вільної Преси.

2. Закон України «Про освіту». № 2145-19. (2017, 5 вересня). Взято 3 http://zakon2.rada.gov.ua/laws/show/2145-19.

3. Карплюк, С.О. (2019) Особливості цифровізації освітнього процесу у вищій школі. Інформаиійно-цифровий освітній простір України: трансформаиійні процеси і перспективи розвитку. Матеріали методологічного семінару НАПН України. 4 квітня 2019 р. (С.188-197). Київ.

4. Концепція «Нова українська школа». (2016, 27 жовтня). Взято 3 http://mon.gov.ua/activity/education/zagalna-serednya/ua-sch-2016/konczepcziya.html

5. Концепція цифрової трансформації освіти і науки на період до 2026 року (проєкт). (2021, 25 травня). Взято 3 https://mon.gov.ua/ua/news/koncepciya-cifrovoyi-transformaciyi-osvitii-nauki-mon-zaproshuye-do-gromadskogo-obgovorennya

6. Кучерак, I. В. (2020). Цифровізація та іiі впив на освітній простір у контексті формування ключових компетентностей. Інноващійна педагогіка, 22(2), 91-94. https://doi.org/10.32843/2663-6085/2020/22-2.20

\section{DEVELOPMENT OF CRITICAL THINKING OF SENIOR PUPILS AT THE IN THE PROCESS OF APPLYING DIGITAL TECHNOLOGIES}

\section{Artem Korkishko}

Candidate of Pedagogical Sciences,

Senior Lecturer of the Department of Pedagogics of Higher School

SHEI "Donbas State Pedagogical University"

Sloviansk, Ukraine

slavpedlicey@ukr.net

() ДВНЗ «Донбаський державний педагогічний університет» 


\author{
Marina Kalmykova \\ Teacher of Ukrainian language and literature, teacher-methodist \\ Sloviansk Pedagogical lyceum of Sloviansk City Council of Donetsk region \\ Sloviansk, Ukraine \\ slavpedlicey@ukr.net
}

\begin{abstract}
Today educational reforms in Ukraine are impossible without active use of digital technologies and development of digital competencies of participants in the educational process, which is reflected in the main educational documents, where the formation of information and digital competence are highlighted among the key core competencies. At the same time, it means the critical application of information and communication technologies for the creation, retrieval, processing, and exchange of information. Of particular importance is the use of digital technologies in the process of acquiring media education and the formation of critical thinking of students that is an important factor of personal development which develops the ability to obtain and process information, analyze and organize material, and improve key educational competencies.

Digital technologies contribute to the development of students' skills to learn independently, and to identify the most valuable material for self-development; the formation of personal mobility, and ability to adapt quickly to changing conditions; strengthening motivation for self-education and self-development; reaching a diverse audience, ensuring the cooperation of participants in the educational process; the construction of individual educational trajectory of students; training in the most convenient conditions at a comfortable pace, with optimal use of time. The experience of teachers and students of Sloviansk Pedagogical Lyceum is positive in this context in creating educational animated videos that combine interesting presentation of the material and demonstration of its application through mastering programs to master Adobe Flash, Easy Gif Animator and Anime Studio. The introduction of digital technologies has allowed students to develop critical thinking, master better the educational material, build an individual educational trajectory, and achieve high learning outcomes.
\end{abstract}

Key words: digitalization of education; digital technologies; critical thinking; media education; information and digital competence

\title{
REFERENCES
}

1. Volosheniuk, O. V. \& Ivanov, V. F. (Ed). (2013). Media education and media literacy: a textbook. Kyiv, Ukraine: Free Press Center

2. Law of Ukraine on education. No 2145-19. (2017, September 5). Retrieved from http://zakon2.rada.gov.ua/laws/show/2145-19

3. Karpliuk, S.O. (2019) Features of Digitalization of the Educational Process in Higher Education. Information and digital educational space of Ukraine: transformation processes and prospects of development. Proceedings of the methodological seminar of the National Academy of Pedagogical Sciences of Ukraine. (2019, 4 April). (P.188-197). Kyiv

4. Concept "New Ukrainian school". (2016, October 27). Retrieved from http://mon.gov.ua/activity/education/zagalna-serednya/ua-sch-

2016/konczepcziya.html

5. Concept of Digital Transformation of Education and Science for the Period Before 2026 (project). (2021, 25 May). Retrieved from https://mon.gov.ua/ua/news/koncepciya-cifrovoyitransformaciyi-osviti-i-nauki-mon-zaproshuye-do-gromadskogo-obgovorennya

6. Kucherak, I. V. (2020). Digitization and its impact on the educational space in the context of the formation of key competencies. Innovative Pedagogics, 22(2), 91-94. https://doi.org/10.32843/2663-6085/2020/22-2.20

Матеріали надійшли до редакції 02.10.2021 p.

Професіоналізм педагога: теоретичні й методичні аспекти. Методичні матеріали до проєкту «Цифровий освітній простір: українсько-польський досвід». - Слов’янськ, 2021. 